\title{
An Annotated Checklist of Finfish and Shellfish Diversity of Pulicat Lake, Southeast Coast of India
}

\author{
N. Jesintha, N. Jayakumar, K. Karuppasamy, B. Ahilan, \\ D. Manikandavelu, A. Uma, K. Madhavi ${ }^{1}$
}

10.18805/IJAR.B-4740

\begin{abstract}
Background: Pulicat lake is the second largest brackish water lagoon in the country, lying partly in Andhra Pradesh and Tamil Nadu states along the Coromandel Coast of South India. The present paper gives information on occurrence, habitat preference, trophic level, human utility and fishery status of finfish and shellfish species of the Pulicat Lake.

Methods: An extensive survey was conducted on finfish and shellfish diversity of Pulicat Lake from November 2019 to March 2021 , selecting four fish landing centres viz, Pazhaverkadu, Arambakkam (fishing villages in Tamil Nadu), Venadu and Vatembedu (fishing villages in Andhra Pradesh) situated along the Lake.

Result: In the present study, A total of 145 species including species of finfishes (95), prawns (8), crabs (7) and 35 molluscs (35) were documented from the Lake. Among the four selected landing centres, the highest diversity was observed in Pazhaverkadu, registering 143 species followed by Arambakkam (123), Vatembedu (85) and Venadu (77).
\end{abstract}

Key words: Checklist, Finfish and shellfish diversity, Pulicat lake, Southeast coast of India.

\section{INTRODUCTION}

Pulicat Lake, located between $13^{\circ} 26^{\prime}$ to $13^{\circ} 43^{\prime} \mathrm{N}$ latitude and $80^{\circ} 03^{\prime}$ to $80^{\circ} 81^{\prime} \mathrm{E}$ longitude, is the second largest brackish water lagoon in the country, lying partly in Andhra Pradesh and Tamil Nadu states on the Coromandel Coast in South India (Fig 1). The lake is an ecological temple, featuring a distinctive and attractive ecosystem, with varied fauna and flora since ancient times. But in the recent years, this fragile ecosystem has been subjected to a variety of ecological crises, both natural as well as man-made such as dynamics of lake mouth, siltation, over fishing, habitat degradation, pollution and illegal aquaculture practices on the lake shoreline. As a result of stress from these natural and anthropogenic inputs not only the biodiversity but also fish catch has been declining. Global Nature Fund, a German-based NGO, which deals with protection of environment and nature, has described Pulicat Lake as the "Threatened Lake of the Year 2010" (Jain, 2010). Knowledge on the present status of fish diversity is the key to sound policy development, better decision making and responsible fisheries management. Hence, an attempt has been made to update the status of finfish and shellfish diversity of Pulicat lake.

\section{MATERIALS AND METHODS}

A total of four sampling stations namely, Pazhaverkadu, Arambakkam (fishing villages in Tamil Nadu), Venadu and Vatembedu (fishing villages in Andhra Pradesh) were selected along the entire stretch of the lake based on abundance of fish species and fishing activities.

Sampling was carried out fortnightly from November 2019 to March 2021. Representative species collected from
Dr. M.G.R Fisheries College and Research Institute, Tamil Nadu Dr. J. Jayalalithaa Fisheries University, Ponneri-601 204, Tamil Nadu, India.

${ }^{1}$ College of Fishery Science, Sri Venkateswara Veterinary University, Muthukur, Nellore-524 001, Andhra Pradesh, India.

Corresponding Author: N. Jayakumar, Dr. M.G.R Fisheries College and Research Institute, Tamil Nadu Dr. J. Jayalalithaa Fisheries University, Ponneri-601 204, Tamil Nadu, India.

Email: jayakumar@tnfu.ac.in

How to cite this article: Jesintha, N., Jayakumar, N., Karuppasamy, K., Ahilan, B., Manikandavelu, D., Uma, A., Madhavi, K. (2021). An Annotated Checklist of Finfish and Shellfish Diversity of Pulicat Lake, Southeast Coast of India. Indian Journal of Animal Research. DOI: 10.18805/IJAR.B-4740.

Submitted: 29-07-2021 Accepted: 22-10-2021 Online: 22-12-2021

fishing boats while being fished and from fish landing centers were stored in ice boxes and brought to the laboratory. In the laboratory, the samples were washed thoroughly and images were captured. Subsequently, the samples were identified up to species level using classical taxonomical methods such as morphometric characters, meristic counts and descriptive characters. Identification of fish species was confirmed using the guides developed by Day (1986), Talwar and Jhingran (1991), Jayaram (1999), Jayaram (2010), Fischer and Bianchi (1984), FAO species identification sheets for fishery purpose (Fishing Area 51) (Fischer and Bianchi, 1984) and FishBase (Froese and Pauly, 2020). Identification of shrimp and crab was confirmed using Sea Life Base (Palomares and Pauly, 2020). As these guides have figurative fish identification keys, the identity of the fishes was established without any ambiguity. Identification 


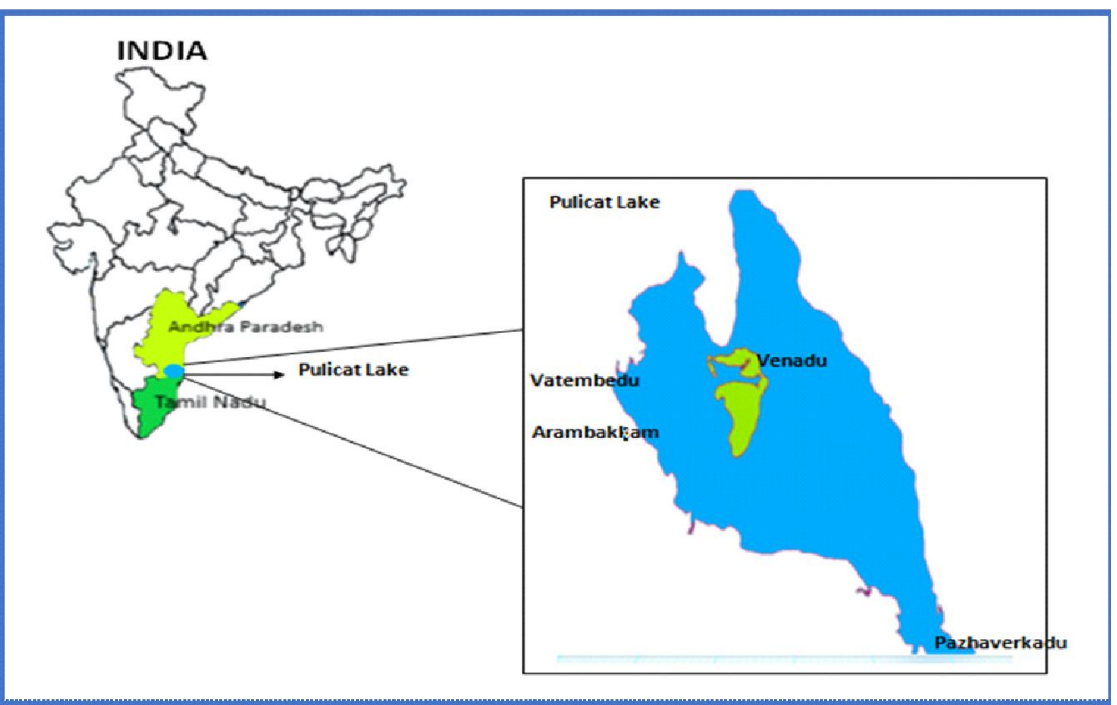

Fig 1: Map showing the study area.

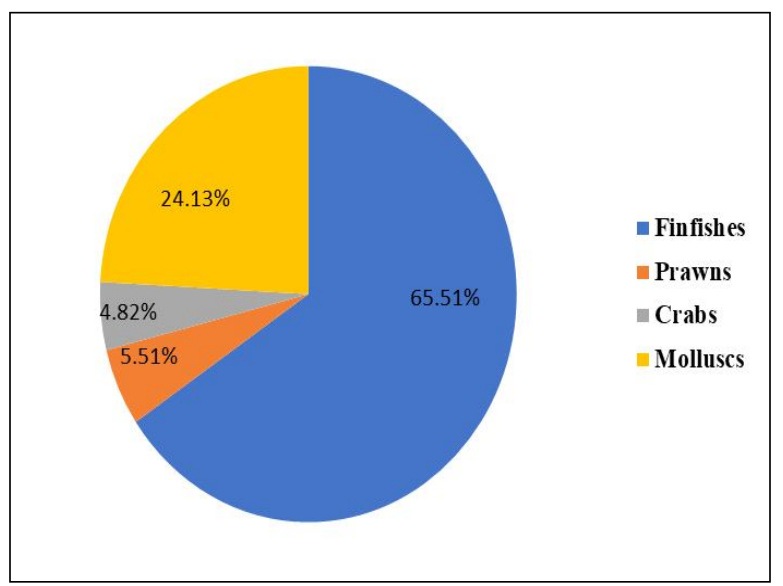

Fig 2: Group-wise representation of fish faunal diversity of Pulicat Lake.

of molluscs was confirmed using the standard keys developed by Richards (1970), Vannucci (2002), Subba Rao (2003), Ramakrishna and Dey (2010), Venkatraman and Venkatraman (2012).

\section{RESULTS AND DISCUSSION}

The present study documented a total of 145 fish species including 95 species of finfish, 8 species of prawns, 7 species of crab and 35 species of molluscs (Fig 2). Mugil cephalus and Strongylura strongylura are found to be dominant species in finfish, whereas Fenneropenaeus indicus is the major species in crustaceans (Table 2 and 3). Further, species diversity was found to be the highest during monsoon (143 species) and the lowest (90 species) during summer.

\section{Finfish diversity}

In the present study, a total of 95 species belonging to 15 orders, 46 families and 73 genera were recorded from the Pulicat Lake (Table 1). Among the 15 orders reported, the order Perciformes was observed to have the highest contribution to the diversity with 54 species followed by Clupeiformes (10 species); Pleuronectiformes (4 species); Siluriformes (with 4 species); Tetraodontiformes (3species); Mugiliformes (3species); Beloniformes (5species); Elopiformes (2species); Ophiocephaliformes (2species) and Scorpaeniformes (2species); Anguilliformes (2species); Aulopiformes (1species); Cypriniformes (1species); Gonorhynchiformes (1species) and Myliobatiformes (1species) (Fig 4).

Among the recorded species of finfish during our study, 14 species were found to be exclusively marine water inhabitants, 40 species were of both brackish water and marine water, 10 species were of both freshwater and brackish water and 31 species were found to be inhabited in all the three environments. The trophic level community structure of recorded fish species revealed the dominance of top-level carnivores (39\%) followed by mid-level carnivores $(28 \%)$, predators (17\%), omnivores (14\%) and herbivores or planktivores $(2 \%)$. The fishery status of recorded finfishes was found to be in the order of commercial $(54 \%)>$ minor commercial $(34 \%)>$ highly commercial $(10 \%)>$ no interest $(1 \%)$. The IUCN status of recorded species was classified mostly as Least Concern (75\%) followed by Not Evaluated (15\%), Data Deficient (6\%), Near Threatened (3\%) and Vulnerable (1\%) (Fig 3).

\section{Shellfish diversity}

During the present survey, 50 species of shellfish including 8 prawns, 7 crabs and 35 molluscs were recorded (Table 1). Among the prawns, the White Prawn (Fenneropenaeus indicus) and the Tiger Prawn (Penaeus monodon) are the major species having export market. Among the crabs recorded, Scylla serrata, S. tranquebarica, Portunus pelagicus, $P$. sanguinolentus are common ones occurring all over the lake. Gastropods and bivalves were found to be the two major classes of the phylum, Mollusca, represented by 35 
Table 1: Checklist of finfish and shellfish diversity of Pulicat Lake.

\begin{tabular}{|c|c|c|c|c|c|}
\hline Scientific name & Family & Habitat & Trophic level & Fishery status & IUCN status \\
\hline \multicolumn{6}{|l|}{ Order: Myliobatiformes } \\
\hline Gymnura poecilura (Shaw, 1804) & Gymnuridae & M & 3.9 & $\mathrm{C}$ & NT \\
\hline \multicolumn{6}{|l|}{ Order: Elopiformes } \\
\hline Elops machnata (Forsskal, 1775) & Elopidae & $B$ and $M$ & 4.0 & $\mathrm{C}$ & LC \\
\hline Megalops cyprinoides (Broussonet, 1782) & Megalopidae & $\mathrm{F}, \mathrm{B}$ and $\mathrm{M}$ & 3.5 & MC & DD \\
\hline \multicolumn{6}{|l|}{ Order: Anguilliformes } \\
\hline Anguilla bengalensis (Gray, 1831) & Anguillidae & $\mathrm{F}, \mathrm{B}$ and $\mathrm{M}$ & 3.8 & $\mathrm{C}$ & NT \\
\hline Anguilla bicolor (McClelland, 1844) & Anguillidae & $\mathrm{F}, \mathrm{B}$ and $\mathrm{M}$ & 3.6 & MC & NT \\
\hline \multicolumn{6}{|l|}{ Order: Aulopiformes } \\
\hline Saurida tumbil (Bloch, 1795) & Synodontidae & M & 4.4 & $\mathrm{C}$ & LC \\
\hline \multicolumn{6}{|l|}{ Order: Clupeiformes } \\
\hline Stolephorus commersonii (Lacepede, 1803) & Engraulidae & $B$ and $M$ & 3.1 & $\mathrm{C}$ & LC \\
\hline Stolephorus indicus (van Hasselt, 1823) & Engraulidae & $\mathrm{B}$ and $\mathrm{M}$ & 3.6 & MC & LC \\
\hline Thryssa purava (Hamiton, 1882) & Engraulidae & $\mathrm{B}$ and $\mathrm{M}$ & 3.5 & MC & DD \\
\hline Thryssa dussumieri (Valenciennes, 1848) & Engraulidae & $\mathrm{B}$ and $\mathrm{M}$ & 2.8 & C & LC \\
\hline Sardinella fimbriata (Valenciennes, 1847) & Clupeidae & $\mathrm{B}$ and $\mathrm{M}$ & 2.7 & C & LC \\
\hline Esculosa thoracata (Valenciennes, 1847) & Clupeidae & $\mathrm{F}, \mathrm{B}$ and $\mathrm{M}$ & 3.2 & C & LC \\
\hline Nematolosa nasus (Bloch, 1795) & Clupeidae & $\mathrm{F}, \mathrm{B}$ and $\mathrm{M}$ & 2.2 & MC & LC \\
\hline Opisthopterus tardoore (Cuvier, 1829) & Clupeidae & $\mathrm{B}$ and $\mathrm{M}$ & 3.4 & MC & LC \\
\hline Ilisha elongata [Anonymous (Bennett),1830] & Pristigasteridae & $B$ and $M$ & 3.8 & $\mathrm{HC}$ & LC \\
\hline Anadontostoma chacunda (Hamilton, 1822) & Clupeidae & $\mathrm{F}, \mathrm{B}$ and $\mathrm{M}$ & 2.8 & $\mathrm{C}$ & LC \\
\hline \multicolumn{6}{|l|}{ Order: Gonorhynchiformes } \\
\hline Chanos chanos (Forsskal, 1775) & Chanidae & $\mathrm{F}, \mathrm{B}$ and $\mathrm{M}$ & 2.4 & $\mathrm{HC}$ & LC \\
\hline \multicolumn{6}{|l|}{ Order: Cypriniformes } \\
\hline Puntius sophore (Hamilton, 1822) & Cyprinidae & $\mathrm{F}$ and $\mathrm{B}$ & 2.6 & MC & LC \\
\hline \multicolumn{6}{|l|}{ Order: Siluriformes } \\
\hline Arius jella (Day, 1877) & Ariidae & $\mathrm{B}$ and $\mathrm{M}$ & 3.5 & $\mathrm{C}$ & NE \\
\hline Plotosus canius (Hamilton, 1822) & Plotosidae & $\mathrm{F}, \mathrm{B}$ and $\mathrm{M}$ & 3.9 & $\mathrm{C}$ & NE \\
\hline Mystus gulio (Hamilton, 1822) & Plotosidae & $\mathrm{F}$ and $\mathrm{B}$ & 4.0 & $\mathrm{C}$ & LC \\
\hline Clarius batrachus (Linnaeus, 1758) & Clariidae & $\mathrm{F}$ and $\mathrm{B}$ & 3.4 & $\mathrm{C}$ & LC \\
\hline \multicolumn{6}{|l|}{ Order: Mugiliformes } \\
\hline Mugil cephalus (Linnaeus, 1758) & Mugilidae & $\mathrm{F}, \mathrm{B}$ and $\mathrm{M}$ & 2.5 & $\mathrm{HC}$ & LC \\
\hline Osteomugil cunnesius (Valenciennes, 1836) & Mugilidae & $\mathrm{F}, \mathrm{B}$ and $\mathrm{M}$ & 2.4 & $\mathrm{C}$ & NE \\
\hline Crenimugil seheli (Forsskal, 1775) & Mugilidae & $\mathrm{F}, \mathrm{B}$ and $\mathrm{M}$ & 2.3 & $\mathrm{C}$ & NE \\
\hline \multicolumn{6}{|l|}{ Order: Beloniformes } \\
\hline Strongylura strongylura (van Hasselt, 1823) & Belonidae & $\mathrm{B}$ and $\mathrm{M}$ & 4.2 & $\mathrm{C}$ & NE \\
\hline Strongylura leiura (Bleeker, 1850) & Belonidae & $\mathrm{B}$ and $\mathrm{M}$ & 3.9 & $\mathrm{C}$ & NE \\
\hline Strongylura crocodiles (Peron and Lesueur, 1821) & Belonidae & M & 4.4 & $\mathrm{C}$ & LC \\
\hline Hyporhamphus limbatus (Valenciennes, 1847) & Belonidae & $\mathrm{F}, \mathrm{B}$ and $\mathrm{M}$ & 3.1 & MC & LC \\
\hline Hyporhamphus unifasciatus (Ranzani, 1841) & Belonidae & $\mathrm{B}$ and $\mathrm{M}$ & 2.0 & MC & LC \\
\hline \multicolumn{6}{|l|}{ Order: Scorpaeniformes } \\
\hline Platycephalus indicus (Linnaeus, 1758) & Platycephalidae & $B$ and $M$ & 3.6 & $\mathrm{C}$ & DD \\
\hline Cociella crocodiles (Cuvier, 1829) & Platycephalidae & $\mathrm{B}$ and $\mathrm{M}$ & 3.9 & $\mathrm{C}$ & LC \\
\hline \multicolumn{6}{|l|}{ Order: Perciformes } \\
\hline Ambassis gymnocephalus (Lecepede, 1802) & Ambassidae & $\mathrm{F}, \mathrm{B}$ and $\mathrm{M}$ & 3.9 & MC & LC \\
\hline Monodactylus argenteus (Linnaeus, 1758) & Monodactylidae & $\mathrm{F}, \mathrm{B}$ and $\mathrm{M}$ & 3.0 & MC & LC \\
\hline Lates calcarifer (Bloch, 1790) & Latidae & $\mathrm{F}, \mathrm{B}$ and $\mathrm{M}$ & 3.8 & $\mathrm{HC}$ & LC \\
\hline Sillago sihama (Forsskal, 1775) & Sillaginidae & $\mathrm{B}$ and $\mathrm{M}$ & 3.3 & $\mathrm{C}$ & LC \\
\hline Rachycentron canadum (Linnaeus, 1766) & Rachycentridae & $\mathrm{B}$ and $\mathrm{M}$ & 4.0 & MC & LC \\
\hline Caranx kalla (Cuvier and Valenciennes, 1833) & Carangidae & M & - & C & LC \\
\hline
\end{tabular}

Table 1: Continue..... 
Table 1: Continue.....

Carangoides praeustus [Anonymous (Bennett), 1830] Carangoides armatus (Ruppell, 1830)

Megalaspis cordyla (Linnaeus, 1758)

Scomberoides lysan (Forsskal, 1775)

Scomberoides tala (Cuvier, 1832)

Trachinotus baillonii (Lacepede, 1801)

Rhabdosargus sarba (Forsskal, 1775)

Nuchequula blochi (Valenciennes, 1835)

Eubleekeria splendens (Cuvier, 1829)

Leiognathus eqqulus (Forsskal, 1775)

Aurigequula fasciata (Lacepede, 1803)

Secutor insidiator (Bloch, 1787)

Lutjanus argentimaculatus (Forsskal, 1775)

Lutjanus ehrenbergii (Peters, 1869)

Lutjanus russelli (Bleeker, 1849)

Lethrinus nebulosus (Forsskal, 1775)

Gerres filamentosus (Cuvier, 1829)

Gerres erythrourus (Bloch, 1791)

Gerres oyena (Forsskal, 1775)

Gerres limbatus (Cuvier, 1830)

Pomadasys maculatus (Bloch, 1793)

Pomadasys argenteus (Forsskal, 1775)

Diagramma pictum (Thunberg, 1792)

Siganus javus (Linnaeus, 1766)

Siganus canaliculatus (Park, 1797)

Scatophagus argus (Linnaeus, 1766)

Parupeneus indicus (Shaw, 1803)

Upeneus tragula (Ricahardson, 1846)

Upeneus vittatus (Forsskal, 1775)

Eleuthronema tetradactylum (Shaw, 1804)

Nibea maculata (Bloch and Schneider, 1801)

Johnius dussumieri (Cuvier, 1830)

Dendrophysa russelii (Cuvier, 1829)

Acanthurus mata (Cuvier, 1829)

Etroplus suratensis (Bloch, 1790)

Pseudetroplus maculatus (Bloch, 1795)

Oreochromis niloticus (Linnaeus, 1758)

Oreochromis mossambicus (Peters, 1852)

Osphronemus goramy (Lacepede, 1801)

Therapon jarbua (Forsskal, 1775)

Therapon puta (Cuvier, 1829)

Therapon theraps (Cuvier, 1829)

Pelates quadrilineatus (Bloch, 1790)

Nemipterus bipunctatus (Valenciennes, 1830)

Nemipterus japonicus (Bloch, 1791)

Psammogobius biocellatus (Valenciennes, 1837)

Glossogobius giuris (Hamilton, 1822)

Sphyraena jello (Cuvier, 1829)

Order: Pleuronectiformes

Brachirus orientalis (Bloch and Schneider, 1801)

Psettodus erumei (Bloch and Schneider, 1801)
Carangidae

Carangidae

Carangidae

Carangidae

Carangidae

Carangidae

Sparidae

Leiognathidae

Leiognathidae

Leiognathidae

Leiognathidae

Leiognathidae

Lutjanidae

Lutjanidae

Lutjanidae

Lethrinidae

Gerreidae

Gerreidae

Gerreidae

Gerreidae

Haemulidae

Haemulidae

Haemulidae

Siganidae

Siganidae

Scatophagidae

Mullidae

Mullidae

Mullidae

Polynemidae

Sciaenidae

Sciaenidae

Sciaenidae

Acanthuridae

Cichlidae

Cichlidae

Cichlidae

Cichlidae

Osphronemidae

Terapontidae

Terapontidae

Terapontidae

Terapontidae

Nemipteridae

Nemipteridae

Gobiidae

Gobiidae

Sphyraenidae

Soleidae

Psettodidae
$M$

$B$ and $M$

$B$ and $M$

$B$ and $M$

$M$

$B$ and $M$

$B$ and $M$

$B$ and $M$

$B$ and $M$

$F, B$ and $M$

$B$ and $M$

$B$ and $M$

$F, B$ and $M$

$F, B$ and $M$

$B$ and $M$

$B$ and $M$

$\mathrm{F}, \mathrm{B}$ and $\mathrm{M}$

$B$ and $M$

$B$ and $M$

$B$ and $M$

$B$ and $M$

$F, B$ and $M$

$M$

$B$ and $M$

$B$ and $M$

$F, B$ and $M$

$B$ and $M$

$B$ and $M$

$B$ and $M$

$F, B$ and $M$ $M$

$B$ and $M$

$\mathrm{F}, \mathrm{B}$ and $\mathrm{M}$

$M$

$\mathrm{F}$ and $\mathrm{B}$

FandB

$F$ and $B$

$F$ and $B$

Fand $B$

$\mathrm{F}, \mathrm{B}$ and $\mathrm{M}$

$F, B$ and $M$

$F, B$ and $M$

$B$ and $M$

$\mathrm{M}$

$M$

$\mathrm{F}, \mathrm{B}$ and $\mathrm{M}$

$F, B$ and $M$

$B$ and $M$

$\mathrm{F}, \mathrm{B}$ and $\mathrm{M}$

$\mathrm{M}$
3.9

4.2

3.9

4.0

4.5

3.6

3.3

2.9

2.9

3.0

3.3

2.8

3.6

3.9

4.1

3.8

3.3

3.3

\section{7}

3.5

4.0

3.5

3.7

2.4

2.8

3.0

3.5

3.6

3.6

\section{1}

3.6

\section{1}

\section{6}

\section{5}

\section{9}

\section{7}

$$
2.0
$$

$$
2.2
$$

2.8

3.9

3.1

3.5

3.6

3.9

4.1

4.1

3.4
3.7

3.7

4.5

3.5

4.4
C

LC

$\mathrm{HC}$

MC LC

MC LC

MC LC

C LC

C NE

C LC

MC LC

MC LC

C NE

C LC

MC LC

C LC

$\mathrm{HC} \quad \mathrm{LC}$

MC LC

MC LC

C LC

C LC

C LC

C LC

C NE

C LC

C LC

MC LC

C LC

C LC

C LC

$\mathrm{HC} \quad \mathrm{NE}$

C LC

MC LC

MC LC

C LC

C LC

C LC

$\mathrm{HC} \quad \mathrm{LC}$

$\mathrm{HC} \quad \mathrm{Vu}$

C LC

MC LC

MC NE

$M C \quad L C$

$M C \quad N E$

MC LC

C LC

$\mathrm{NI} \quad \mathrm{LC}$

MC LC

C NE

C LC

C DD

Table 1: Continue..... 
Table 1: Continue.....

Cynoglossus punticeps (Richardson, 1846)

Cynoglossus semifasciatus (Day, 1877)

Order: Tetradontiformes

Chelonodon patoca (Hamilton, 1822)

Lagocephalus inermis (Temminck and Schlegel, 1850)

Triacanthus biaculeatus (Bloch, 1786)

Order: Ophiocephaliformes

Channa punctatus (Bloch, 1793)

Channa striata (Bloch, 1793)

Order: Decapoda

Penaeus monodon (Fabricius, 1798)

Peneaus semisulcatus (Bloch, 1793)

Penaeus canaliculatus (Fabricius, 1798)

Penaeus merguiensis (De Man, 1888)

Fenneropeneaus indicus (Milne-Edwards, 1837)

Metapenaeus dobsoni (Miers, 1878)

Metapenaeus affinis (Milne-Edwards, 1837)

Metapenaeus monoceros (Fabricius, 1798)

Portunus pelagicus (Linnaeus, 1758)

Portunus sanguinolentus (Herbst, 1783)

Scylla serrata (Forsskal, 1775)

Scylla tranquebarica (Fabricius, 1798)

Charybdis natator (Herbst, 794)

Charybdis cruciata (Herbst, 1794)

Charybdis lucifera (Fabricius, 1798)

Order: Littorinimorpha

Bufonaria rana (Linnaeus, 1758)

Eunaticina papilla (Gmelin, 1791)

Nautica lineate (Roding, 1798)

Nautica vitellus (Linnaeus, 1758)

Polnices tumidus (Swainson, 1840)

Bufonaria echinata (Link, 1807)

Order: Neogastropoda

Babylonia zeylanica (Bruguiere, 1789)

Fusinus colus (Linnaeus, 1758)

Turbinella pyrum (Linnaeus, 1767)

Harpa major (Roding, 1798)

Chicoreus virgineus (Roding, 1798)

Murex trapa (Roding, 1798)

Pugilina conchlidium (Linnaeus, 1758)

Indothias lacera (Born, 1778)

Gemmula unedo (Kiener, 1840)

Nassarius luridus (Gould, 1850)

Oliva caerulea (Roding, 1798)

Oliva oliva (Linnaeus, 1758)

Rapana rapiformis (Born, 1778)

Order: Caenogastropoda

Telescopium telescopium (Linnaeus, 1758)

Turritella attenuata (Reeve, 1849)

Rhiniclavis sordidula (Gould, 1849)
Cynoglossidae

Cynoglossidae

Tetradontidae

Tetradontidae

Triacanthidae

Channidae

Channidae

Penaeidae

Penaeidae

Penaeidae

Penaeidae

Penaeidae

Penaeidae

Penaeidae

Penaeidae

Portunidae

Portunidae

Portunidae

Portunidae

Portunidae

Portunidae

Portunidae

Bursidae

Naticidae

Naticidae

Naticidae

Naticidae

Bursidae

Buccinidae

Fasciolaridae

Turbinellidae

Harpidae

Muricidae

Muricidae

Melongenidae

Muricidae

Turridae

Nassariidae

Olividae

Olividae

Muricidae

Potamididae

Turritellidae

Cerithlidae

\section{$\mathrm{F}, \mathrm{B}$ and $\mathrm{M}$}

$\mathrm{M}$

F, B andM

$M$

$B$ and $M$

$F$ and $B$

$F$ and $B$

\section{B}

B

B

B

B

B

$B$ and $M$

$B$

$B$ and $M$

$B$ and $M$

$B$

B

$M$

$M$ and $B$

B

3.3

3.4

C

C

LC

DD

3.1

3.9

2.8

$\mathrm{MC}$

$\mathrm{MC}$

$\mathrm{MC}$

3.8

3.6

C

$\mathrm{HC}$

$$
3.4
$$$$
2.9
$$$$
-
$$

$>2.8$

$$
3.3
$$

$$
3.5
$$

3.9

3.3

3.5

3.6

3.5

$-$

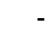

2.2-2.79

$$
\text { M }
$$

M

$M$

$M$

M

M

-

C

C

C

C

C

C

$\mathrm{HC}$

C

$\mathrm{HC}$

C

C

C

C

C

$$
\text { C }
$$

LC

LC

NE

LC
LC

NE

NE

NE

NE

NE

NE

NE

NE

NE

$$
\text { NE }
$$

NE

$$
\text { NE }
$$

NE

NE

NE

NE

NE

NE

NE

NE

NE

NE

NE

$\begin{array}{llll}F, B \text { and } M & 3.0 & - & N E\end{array}$

M $>2.8$

$\mathrm{M}$

$\mathrm{M}$

$M$

$M$

$M$

$M$

$\mathrm{M}$

$\mathrm{M}$

M

$-$

$>2.8$

3.2

$>2.8$

$-$

-

$-$

$>2.8$

$>2.8$

$B$ and $M$

2-2.19

$M$

M
$-$

2-2.19

\section{NE}

$$
\text { NE }
$$

\section{NE}

NE

NE

NE

NE

NE

NE

NE

LC

NE

NE

Table 1: Continue..... 
Table 1: Continue......

\section{Order: Heterostropha}

Architectonica perspectiva (Linnaeus, 1758)

Order: Trochida

Umbonium vestiarium (Linnaeus, 1758)

Order: Venerida

Paphia textile (Gmelin, 1791)

Mactra antiquata (Spengler, 1802)

Gafrarium tumidum (Roding, 1798)

Paphia malabarica (Dillwyn, 1817)

Order: Arcida

Anadara granosa (Linnaeus, 1758)

Order: Pectinida

Placuna placenta (Linnaeus, 1758)

Order: Ostreida

Crossostrea madrasensis (Preston, 1916)

Pinna bicolor (Gmelin, 1791)

Order: Cardiida

Donax cuneatus (Linnaeus, 1758)

Tellina cancellata (Gmelin, 1791)

Order: Mytiida

Perna viridis (Linnaeus, 1758)

$\begin{array}{ccccc}\text { Architectonicidae } & \text { M } & >2.8 & \text { C } & \text { NE } \\ \text { Trochidae } & \text { B } & 2-2.19 & \text { C } & \text { NE } \\ \text { Veneridae } & \text { M } & 2-2.19 & \text { C } & \text { NE } \\ \text { Mactridae } & \text { M } & - & - & \text { NE } \\ \text { Veneridae } & \text { M } & 2.0 & - & \text { NE } \\ \text { Veneridae } & \text { B } & - & \text { C } & \\ \text { Arcidae } & \text { B } & 2.0 & \text { C } & \text { NE } \\ \text { Placunidae } & \text { B and M } & - & & \text { NE } \\ \text { Ostreidae } & \text { B } & 2.3 & \text { C } & \text { NE } \\ \text { Pinnidae } & M & 2-2.19 & C & \text { NE } \\ \text { Donacidae } & \text { M } & 2-2.19 & - & \text { NE } \\ \text { Tellinidae } & \text { M } & - & - & \text { NE } \\ \text { Mytilidae } & \text { B } & 2-2.19 & \text { HC } & \text { NE }\end{array}$

F: Freshwater, B: Brackish water; M: Marine water; C: Commercial, MC: Minor Commercial, HC: Highly Commercial; LC: Least Concern, NE: Not evaluated.

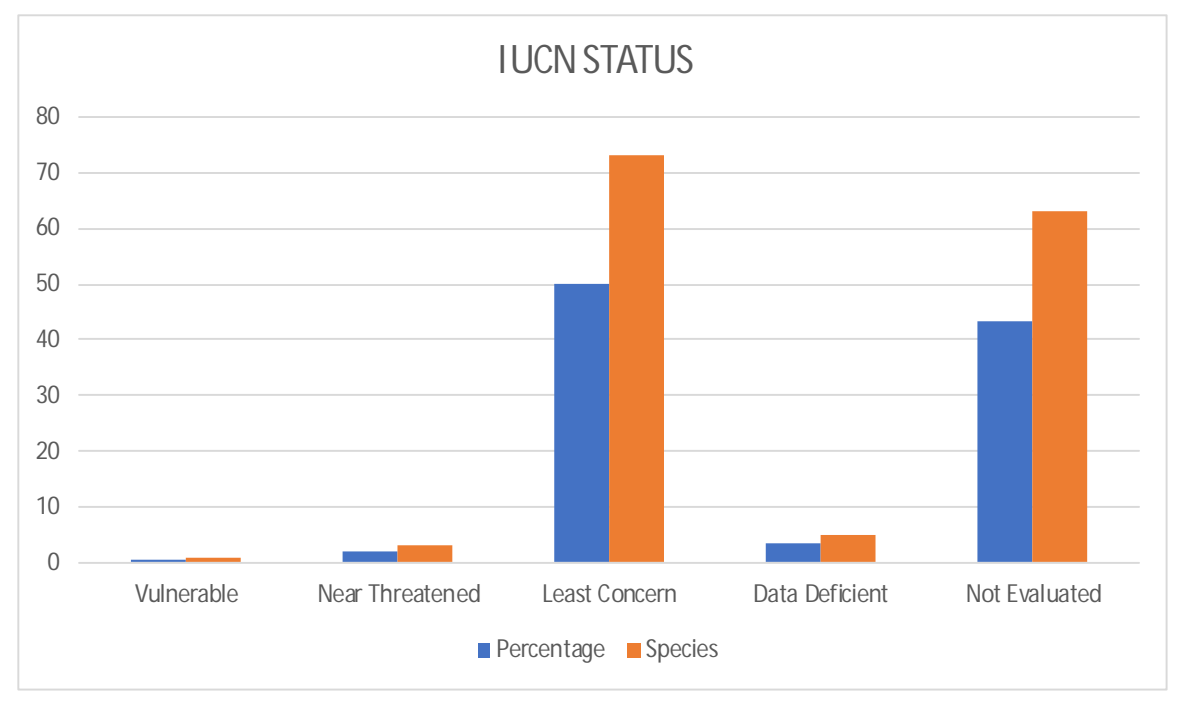

Fig 3: IUCN Status of finfish and shellfish.

species belonging to 26 families. Gastropod included 17 families, 21 genera and 24 species and bivalve included 9 families, 10 genera and 11 species.

Among the 50 species recorded, 27 species were exclusively marine, 15 species were brackish water, 6 species were freshwater cum brackish water and the remaining 2 species were inhabitants of all the three environments. The trophic level analysis shows that shellfish composition was dominated by mid-level carnivores (13 species) followed by herbivores or planktivores (9), top-level carnivores (6) and omnivores (2) and trophic level of remaining 20 species could not be assessed from the available literature. The fishery status of 22 species was found to fall under commercial category followed by high commercial category (3 species). The analysis of IUCN status revealed that almost all species (49 species) fall under Not Evaluated (NE) category except one under Least Concern (LC) category (Fig 3).

During the present research, a considerable difference in the number of fin and shell fishes has been observed with respect to the earlier reports, viz., Raj (2006), who reported 168 species of fishes, 12 species of prawns and 19 species of crabs from the lake, Govindan and 
Ravichandran (2016), who could record 83 finfish species belonging to 14 orders and 50 families from the lake, while, Saraswathy and Pandian (2016) recorded 81 species of fishes, 5 species of prawns and 3 species of crabs, whereas, Ramanibai and Govindan (2018) recorded 51 species of molluscs including gastropods (34) and bivalves (17) from the lake. Comparing the data of present research with the literature of Raj (2006), it is quite clear that there is visible decline of fish diversity and the same has been witnessed even in the case of molluscan diversity compared to the results of Ramanibai and Govindan (2018).
Among the four selected landing centres, highest diversity has been observed in Pazhaverkadu, documenting 143 species followed by Arambakkam (123 species), Vatembedu (85 species) and Venadu (77 species). The observed high diversity at southern landing centres (Pazhaverkadu and Arambakkam) compared to northern centres (Vatembedu and Venadu) could be attributed to their proximity to the sea mouth at Pulicat village, the only active sea mouth of Pulicat lake as of now, as sea mouths of the lagoon generally serves as recruitment corridors for fish and shellfish from the sea into the lake. The observed,

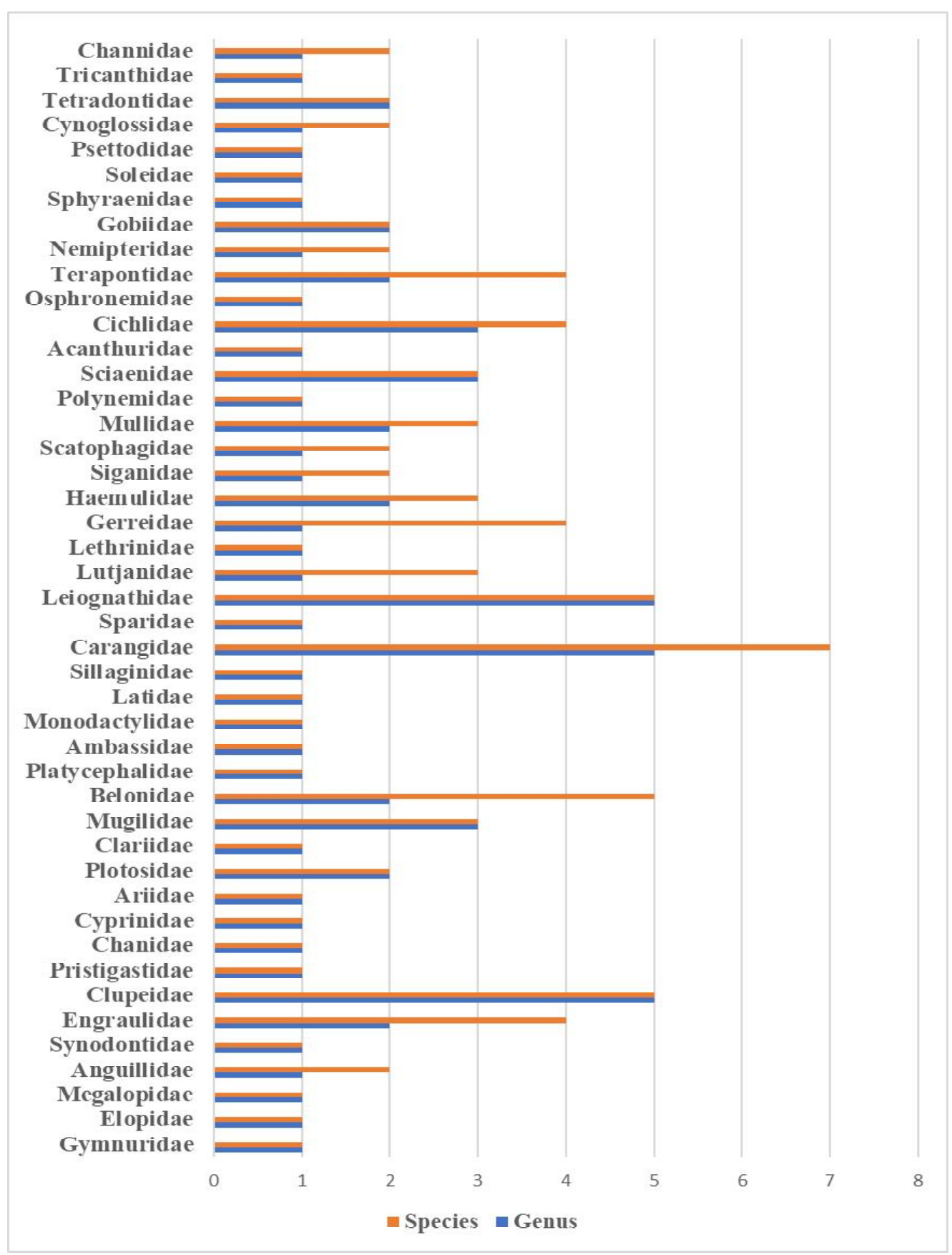

Fig 4: Family-wise representation of finfish diversity of Pulicat Lake. 
Table 2: Dominant species of finfishes.

\begin{tabular}{lc}
\hline Species & Abundance (in number) \\
\hline Mugil cephalus & 463885 \\
Strongylura strongylura & 391760 \\
Stolephorus commersonii & 360590 \\
Hemiramphus limbatus & 359560 \\
Stolephorus indicus & 300900 \\
Chanos chanos & 246880 \\
Sillago sihama & 170570 \\
Elops machnata & 159735 \\
Mugil cunnesius & 125210 \\
Gerres filamentosus & 103960 \\
\hline
\end{tabular}

Table 3: Dominant species of crustaceans.

\begin{tabular}{lc}
\hline Species & Abundance (in number) \\
\hline Shrimps & \\
Fenneropenaeus indicus & 4824688 \\
Penaeus monodon & 1661160 \\
Crabs & \\
Scylla serrata & 224580 \\
Portunus pelagicus & 83380 \\
Portunus sanguinolentus & 68370 \\
Scylla tranquebarica & 66460 \\
\hline
\end{tabular}

comparatively less diversity at northern landing centres (Vatembedu and Venadu) might be due to their proximity to the sea mouths at Tupilipalem, Rayadoruvu (northern side), where, they had already been significantly narrowed down due to sand bar formation and this might be responsible for the drying of the lake and decline in fish wealth as has been expressed by Ravikiran (2017).

Over the past few years, the Lake has been experiencing intense and sustained stresses, both natural as well as manmade, as a result, biodiversity and fisheries in the lake has been declining so fast. Among the multitude of factors identified responsible for the observed decline in fin and shell fish diversity, 'lake mouth dynamics' and 'siltation of the lake' appeared to be the significant natural stressors, while 'capturing of immature fish and prawns', 'destruction of mangroves and their associates', 'deterioration of water quality', 'hand picking of juvenile shell fishes', 'non implementation of fishery acts and legislation and illegal capturing of earth worms on a large scale seemed to be significant anthropogenic stressors.

\section{CONCLUSION}

On the basis of our research findings and other similar studies of recent times, it can be concluded that, Pulicat lagoon has been losing its biological productivity under the influence of natural as well as human interference and hence it is recommended to pay at most attention towards conservation and management of Pulicat Lake fisheries diversity. Keeping the lake mouth open throughout the year, widening the existing sea mouth or making the northern mouths (at least one among the two) active; effective regulation on mesh size and fishing gear to prevent over exploitation are much needed. Planting of mangrove saplings around the lake should be carried out on a priority basis for lake restoration. Strict implementation of existing 'conservation and management measures' with raising public awareness would be essential to save the fish germplasm of this lagoon and it's time to formulate appropriate management measures to safeguard the varied heritage of Pulicat lake i.e., its rich fish and shellfish biodiversity.

\section{REFERENCES}

Day, F. (1986). The fishes of India: Being a natural history of the fishes known to inhabit the seas and fresh waters of India, Burma and Ceylon. Vol I. Today and Tomorrow's Book Agency, New Delhi. 778.

Fisccher, W. and G. Bianchi (eds.) (1984). FAO Species Identification Sheets for Fishery Purposes. Western Indian Ocean (Fishing Area 51). Rome: FAO. Volumes 1-6. http://www. fao.org/docrep/009/ad468e/ad468e00.htm.

Froese, R., Pauly, D. (eds.) (2020). Fish Base. [version 12/2020] http://www.fishbase.org.

Govindan, S. and Ravichandran, R., (2016). Fish Fauna Diversity and Conservation Status of Pulicat Lagoon in Tamil Nadu. Annals of Aquaculture and Research. 3(2): 1018.

Jain, N., (2010). Pulicat-threatened lake of the year 2010. Current Science. 99(11): 1496.

Jayaram, K.C. (1999). The Fresh Water Fishes of the Indian Region. Narendra Publishing House, Delhi, 551.

Jayaram, K.C. (2010). The Freshwater Fishes of the Indian Region. Revised $2^{\text {nd }}$ ed. Delhi: Narendra Publishing House. 616.

Palomares, M.L.D. and Pauly, D. (eds.) (2020). Sea Life Base. [version 12/2020] http://www.sealifebase.org.

Ramakrishna and Dey, A. (2010). Annotated Checklist of Indian Marine Molluscs (Cephalopoda, Bivalvia and Scaphopoda), Part-I, Records of the Zoological Survey of India, Occasional Paper. 320: 1-357.

Ramanibai, R. and Govindan, S. (2018). Mollusc diversity at pulicat Lagoon (India). Transylvanian Review of Systematical and Ecological Research. 20(1): 31-42.

Richards, C.S. (1970). Genetics of a Molluscan Vector of Schistosomiasis, Nature. 227: 806-810.

Ravikiran, G. (2017) States's decision kindles hopes of Pulicat fishermen families. The Hindu, September 18.

Sanjeeva Raj, P.J. (2006). Macro fauna of Pulicat Lake. NBA bulletin, 6. Saraswathi, R. and Pandian, P.K., (2016). Pulicat Lake: A Fragile Ecosystem under Threat. Slovak Journal of Civil Engineering. 24(3): 8-18.

Subba Rao, N.V. (2003) Indian Seashells, I, Polyplacophora and Gastropoda, Edit. Director, Zoological Survey of India. $1-426$.

Talwar, P.K. and A.G. Jhingran (1991). Inland Fishes of India and Adjacent Countries, Oxford and IBH Publishing Co. Pvt. Ltd. New Delhi-Calcutta. 1: 382-383.

Vannucci, M. (2002). Indo-west Pacific Mangroves, In: Mangrove Ecosystems, [Lacerda, L.D. (ed.)], Springer, Berlin. 122-215.

Venkatraman, C. and Venkataraman, K., (2012). Diversity of Molluscan Fauna along the Chennai Coast, May $22^{\text {nd }}$ International day for Biological Diversity Marine Biodiversity. 29-35. 